\title{
Non-Invasive Pancreatic Mucinous-Cystic Neoplasm
}

National Cancer Institute

\section{Source}

National Cancer Institute. Non-Invasive Pancreatic Mucinous-Cystic Neoplasm. NCI

Thesaurus. Code C95488.

A cystic epithelial neoplasm characterized by the presence of columnar mucin-producing epithelial cells, ovarian-type stroma formation, and the absence of an invasive carcinomatous component. 